\title{
A XICANISTA (RE)VISION OF A CONTEMPORARY MALINCHE IN ANA CASTILLO'S THE MIXQUIAHUALA LETTERS (1986)
}

\author{
Maria Ntokli \\ Aristotle University of Thessaloniki*
}

\begin{abstract}
This article investigates how Ana Castillo revisits the archetype of La Malinche as a female traitor in her epistolary novel The Mixquiahuala Letters. Castillo unravels her feminist perspective in order to subvert the sexist connotations associated with La Malinche, and draws from this specific female figure in the creation of her Chicana protagonist, narrator and letter-writer. Teresa represents a contemporary reinvention of La Malinche, a character who exposes the sexist double standards Chicanas are subjected to. In this way, Castillo delves into the Chicana experience and proposes a Xicanista vision that emphasizes the understanding of the past in order to be able to envision a better future.
\end{abstract}

Keywords: La Malinche, Malinchista, Machismo, Xicanisma.

\section{UNA (RE)VISIÓN XICANISTA DE UNA MALINCHE CONTEMPORÁNEA EN THE MIXQUIAHUALA LETTERS (1986) DE ANA CASTILLO}

\section{RESUMEN}

Este artículo investiga cómo Ana Castillo revisita el arquetipo de La Malinche como mujer traidora en su novela epistolar The Mixquiahuala Letters. Castillo utiliza una perspectiva feminista, para subvertir las connotaciones sexistas asociadas con La Malinche, y se inspira en esta figura femenina para la creación de la protagonista y narradora chicana que escribe las cartas en la novela. Teresa representa una reinvención contemporánea de La Malinche, un personaje que expone la doble moral del sexismo al que están sometidas las mujeres chicanas. De esta manera, Castillo indaga en la experiencia chicana, y propone una visión Xicanista que enfatiza la comprensión del pasado para poder visualizar un futuro mejor.

Palabras Clave: La Malinche, malinchista, machismo, Xicanisma.

DOI: https://doi.org/10.25145/j.recaesin.2020.81.16 
Pinche, como duele ser Malinche...

Pero sabes, ése,

What keeps me from shattering into a million fragments?

It's that sometimes, you are muy gringo, too. ${ }^{1}$ -Adaljiza Sosa Riddell (1973) (qtd. in Pratt 862)

La Malinche, also known as Malintzin, Malinalli or Doña Marina, is a controversial historical figure associated with the conquest of the Aztec Empire by the Spanish conquistadores (1519-1521), a woman who has been the subject of many debates and rewritings by Mexican and Chicana/o writers. Octavio Paz has elaborated on the negative connotations of Malinche's significance in Mexican national mythology, in which she functions as the symbolic mother of Mexico's mestiza/o people, because of her "illicit relationship" with Hernán Cortés (qtd. in Pratt 860). According to Mary Louise Pratt, in Mexican vernacular, malinche and malinchista are derisive terms meaning "traitor" of the nation, or "a person who adopts foreign values, assimilates to foreign culture, or serves foreign interests" (860). Ana Castillo, however, states that in recent years, "feminist writers have reinterpreted Malintzin in a variety of ways," and that by "viewing her with compassion," they have attempted to "clarify how the patriarchal conquest ultimately left this young Mexic-Amerindian woman little choice but to obey in the name of God the Father" (Massacre 166-167). La Malinche is not an overt reference in the epistolary novel The Mixquiahuala Letters, but according to Harryette Mullen, she is "an almost subliminal allusion" (4). In fact, Castillo uses elements of what Sandra Messinger Cypess calls "The Malinche Paradigm as Subtext" (153), ${ }^{2}$ along with introducing new ones that perform a reinvention of the archetype. This article examines how Castillo draws from the figure of La Malinche in the creation of Teresa, the Chicana protagonist and narrator of The Mixquiahuala Letters, in order to undermine the misogynistic connotations associated with La Malinche and ultimately revise this specific female archetype. By creating a multilayered representation of a latetwentieth-century Chicana, Castillo essentially proposes a feminist or Xicanista ${ }^{3}$ revision of Chicana/o literature and culture as an alternative to previous androcentric

* Research for this paper has been carried out in Partial Fulfilment of the Requirements for the Degree of Master of Arts in English and American Studies at the School of English, Aristotle University of Thessaloniki, Greece. My deepest gratitude goes to Dr. Sophia Emmanouilidou for introducing me to Chicana/o Studies and for her guidance as a supervisor of this research paper. very Anglo."

1 Translation of Spanish: "Damn, how it hurts to be Malinche... / But you know, man, /

${ }^{2}$ Cypess applies this framework in her analysis of certain works by Carlos Fuentes, Elena Garro and others. The critic identifies defining elements, such as betrayal, cultural assimilation, rape or a woman "used as an object of exchange," that allude to La Malinche (153-155).

${ }^{3}$ Castilo coins the term Xicanisma to replace Chicana Feminism. For more on Castillo's subversive response to the pre-existing androcentric nationalism, see Massacre of the Dreamers. 
interpretations of the female experience, and also subverts the established patriarchal narrative of La Malinche as a traitor.

Castillo suggests multilayered connections between La Malinche and Teresa, and in order to revise sexist and derogatory narratives of La Malinche, she foregrounds Teresa as a "malinchista" character, at least according to the standards imposed by patriarchy and machismo. ${ }^{4}$ Teresa is perceived as a "malinchista" primarily due to her higher education, her feminist ideology and her reluctance to blindly abide by traditions, which result in the abandonment of her husband. More specifically, Teresa is a working-class Chicana from Chicago, who puts great effort in getting a higher education, a woman who "took [her] final exams" and graduated from the university (Letters 35$), 5$ when she was already married at twenty-one. Moreover, Teresa spends the summer after her graduation away from her husband, "bound in that yet undefined course known as The New Woman's Emergence" (35), with her best friend Alicia, whom she met a year earlier when they were both twenty, studying in Mexico. As a result, Teresa becomes the target of "silent condemnation," because "relatives and friends" believe that "'bad wives' were bad people" (35). An example of this is when Teresa's godmother, Rosaura, who considers her behavior "sacrilegious," warns her: "According to the Church, even if you get a divorce, you'll always be married and you'll live in sin with any other man" (21-22). However, in spite of the disapproval of her community, Teresa leaves her husband several times to travel to Mexico or New York to see Alicia, as she is on a "Woman's Quest for Freedom and Self Determination," and even though she goes back to him (37), she is not prepared to "honor patriarchal traditions" (28). The term Malinche "first entered the Chicano movement in its established popular meaning as "traitor" (Pratt 862), and this derisive label according to Evangelina Enríquez and Alfredo Mirandé is "applied to Chicanas who left the community to seek higher education, a move regarded as assimilating to white culture, and to Chicanas who allied themselves with feminism" (qtd. in Pratt 862). Thus, even though Teresa is not directly called a "malinchista," the fact that she rejects patriarchal expectations that hinder women's free will, makes people in her community perceive her as a traitor. In addition, an important paradox that arises is that Teresa is seen as a "malinchista," mainly for betraying the androcentric Catholic tradition and despite her desire to reconnect with the indigenous part of her heritage that leads her back to Mexico time and again.

Castillo proposes a Chicana feminist vision that reinvents the established patriarchal narrative of La Malinche, by centering on Teresa and Alicia's close friendship, a relationship that unfolds through Teresa's first-person fragmentary

${ }^{4}$ According to Castillo, "machismo is an exaggerated demonstration of male virility that is inherent in most cultures," including the Mexican and the Anglo. As regards the Mexican and Chicana/o cultures, one can trace the origins of machismo and male supremacist practices in the Mexican Catholic Church, but also in the Aztec civilization (Massacre of the Dreamers 14).

5 Quotations from Ana Castillo's 1986 novel The Mixquiahuala Letters follow the Anchor Books 1992 edition to which I refer as Letters for brevity. 
narration of their past adventures in her letters to Alicia. This is evident in Letter Three, where Teresa declares openly her allegiance to her own gender, instead of to a man or even her husband. Alicia, a North American of Spanish descent, described as a "privileged white girl of the suburbs" of New York (Letters 48), becomes Teresa's "sister, companion" and "friend" to whom her letters are "addressed and signed with the greatest affirmation of allegiance ... In sisterhood. In solidarity" (24). Teresa also narrates how she met Alicia at an almost "fraudulent" NorthAmerican institution with a "heavy Aztec name" in Mexico City, in which they both enrolled to study Mexico's culture and language, only to find "gringo instructors," who "didn't speak Spanish," much to Teresa's disappointment (24-25). In fact, the highlight of that "summer of [their] fledgling womanhood" is when Teresa and Alicia visit "Mixquiahuala, a Pre-conquest village" (25). Barbara F. Weissberger emphasizes that "as Teresa's privileged addressee, Alicia is essential to the letterwriter's own search for self-knowledge," given that Alicia "is the focus of Teresa's reexamination of her past" (12). In addition, Teresa goes to Mexico after having left her "embittered" husband to run off "on her own for two months" (Letters 28). In this light, Teresa "is an insurgent" (Massacre 177), ${ }^{6}$ and while she "evolves as a feminist, she is placed in the dangerous position of being viewed as a traitor to the male-dominated Chicano Movement" (178). Hence, Castillo further establishes Teresa as a contemporary subversive revision of La Malinche by highlighting the fact that she chooses to form an allegiance with Alicia, a woman outside of her community, a character who becomes Teresa's partner in crime as she embarks on a journey of self-discovery across Mexico. What is more, Teresa's journey reverses the historical tale of how La Maliche was practically forced by a strict patriarchal society into accompanying Hernán Cortés on his conquest of Mexico as his aide and interpreter. In other words, La Malinche was forced to serve a man's mission and interests; whereas Teresa is on a mission of her own and enjoys a partnership between equals, despite class and race differences.

Moreover, men are not that important in Teresa's journey of self-discovery. In reality, aside from inflicting various forms of painful psychological abuse on both Teresa and Alicia, men's influence on either one of them is secondary. This is evident in the way Teresa describes her relationship with Alicia by implying that this is the most significant relationship for both of them. Teresa redirects the importance usually attributed to heterosexual romantic relationships into a female friendship by saying that "ours was a love affair" (Letters 45), "ours was a relationship akin to that of an old wedded couple" (53). Weissberger claims that Teresa and Alicia's friendship "remains the one stable and mutual relationship in both their lives throughout the decade after the Mexican journey" (12). In addition, during their stay in Mexico, Alicia disapproves of Teresa's "gold band on the wedding finger" (Letters 25), so later she tells Teresa that she has "no business being married" and finds it incomprehensible

${ }^{6}$ Quotations from Ana Castillo's Massacre of the Dreamers: Essays on Xicanisma follow the Plume 1995 edition to which I refer as Massacre for brevity. 
that any woman of their generation could "willingly commit herself to slavery" (38). Castillo suggests that by befriending "a burgeoning feminist" like Alicia, Teresa begins a "confrontation with herself as a conventional married woman from a conservative Mexican upbringing" (Massacre 177). Therefore, it is the defiant nature of this female friendship between Teresa and Alicia that further renders Teresa as a character likely to be interpreted as a "malinchista" by her community, given that she is in search of self-determination away from oppressive, male-centered, preconceived notions of how a woman should be. At the same time, this female friendship gives the novel a subversive, feminist, dialectical quality that questions the derogatory characterization of Chicanas as traitors for choosing to follow their own path and, thus, Castillo puts forward a new type of Chicana identity defined by feminist ideology.

Teresa, however, is not a traitor; as a young woman in her early twenties, she is simply in search of her own identity. In fact, both La Malinche and Teresa could be described as border-crossers. Teresa's identity is essentially hybrid and, ultimately, represents mestizaje and in-betweenness, since she functions as a bridge between cultures, between North America and Mexico, in a way that brings to mind how La Malinche acted as a mediator and interpreter between the Spanish culture and the Aztec civilization. One example of this is when Teresa explains during "a battle of wits" to Ponce, a young Mexican engineer, what "a liberal woman" is, after he asks her in a patronizing manner if she is one (Letters 78-79). Teresa understands that in Mexico, "the term 'liberated woman' mean[s] something other than what [women have] strived for back in the United States," it "simply mean[s] a woman who would sleep nondiscriminately with any man" (79). Thus, Teresa as a perceptive bordercrosser gets the upper hand by replying intelligently to Ponce: "What you perceive as 'liberal' is my independence to choose what i do, with whom, and when. Moreover, it also means that i may choose not to do it, with anyone, ever" (79). Guillermo Gómez-Peña argues that the hybrid or mestiza must be understood, as a "crosscultural diplomat, as an intellectual coyote (smuggler of ideas)" (qtd. in Carson 114), and Cordelia Candelaria points out that the story of La Malinche "might be read as an account of the prototypical Chicana feminist," as she embodies intelligence and adaptability (6). Benjamin D. Carson claims that as border-crossers, Teresa and Alicia "have a tenuous relationship with both Mexico and the United States; both, in a sense, are alien to them, because, as mestizas, they live not in one culture, but between and among several cultures" (116). In view of the above, it could be argued that Teresa's identity of a border-crosser, as well as her intelligence as a Chicana feminist, one who has to navigate different spaces, alludes to Malinche's impressive skills of adaptation, as she also lived between different cultures.

The theme of betrayal, which is inextricably intertwined with La Malinche due to a deeply ingrained patriarchal ideology and La Maliche's alleged role in the European Conquest of Mexico, is further explored in the novel, but Castillo subverts the sexist belief that betrayal is an innate characteristic of the female gender. As aforementioned, Teresa is the one who abandons her husband to find herself in Mexico accompanied by Alicia, a decision which is seen as the betrayal of a "malinchista" due to her refusal to uphold the traditionally assigned role of 
a submissive wife. However, Teresa, and other women in the novel repeatedly fall victims to various forms of betrayal perpetrated by Mexican men. This becomes evident when Teresa mentions that Señor Aragón, a Mexican copperwork instructor, "was particularly concerned with the progress of his blond students" from Texas and New Jersey (Letters 26-27), whereas he disliked Teresa presumably because of her "Indian-marked face" (25), her "dark skin" (67) and her "dark hair," which must have made her appear "like the daughter of a migrant worker or a laborer in the North" (27). Thus, Señor Aragón favors his blond students over Teresa, because he does not consider a female student of indigenous descent worthy of his attention. Another example of a Mexican man who betrays his Mexican "complacent wife" in order to have an affair with "a hot, young gringa" (35), who unwittingly happens to be Alicia, is Adán, "the Indian caretaker" of an unoccupied hotel in Acapulco (32). Adán does not think twice before betraying his "inconsequential" wife from the village for the sake of making "love to the infamous North American white woman" (33). Castillo emphasizes that "[s]ubversion of all implied truths is necessary in order to understand the milieu of sexist politics that shape the lives of women" (Massacre 176-77). Thus, despite the fact that Teresa is proud of her indigenous heritage and seems to be overall confident about her physical appearance, which diverges from Eurocentric beauty standards imposed by Colonialism, Mexican men seem to have internalized these beauty myths and hold them in high regard. As a result, Teresa experiences discrimination and a dual sense of rejection and betrayal.

Another important example of male betrayal that undermines the patriarchal myth of female treachery, at least as personified in the archetype of La Malinche, is enacted by Sergio Samora, a wealthy Mexican heir and Teresa's "entrepreneur-suitor" (Letters 66-67). Teresa suggestively calls her relationship with Sergio "the Yucatán saga" (70), because he invites her to stay at his hacienda in Mérida (90). Sergio promises Teresa "a new life free of hardship" (99), he proposes marriage to her and tells her that she will become his assistant and "his interpreter" after the marriage (67), a role that directly links Teresa to La Malinche. However, during a house party hosted by Sergio, Teresa faces a confusing experience. Sergio, who surrounds himself with women from Belgium and Switzerland, "toasted to the incomparable bronze skin of the tropical woman" and "all his friends reached high up with filled glasses and smiled with open admiration at [Teresa's] indigenous heritage" (66). Teresa concludes this scene by saying "i know now what a mockery that was" (66), as she speaks in hindsight after Sergio has jilted her via a melodramatic telegram (99), hence implying that during the party, members of the Mexican elite actually made fun of her indigenous ancestry by treating her as a token and essentializing her indigeneity. Moreover, after this incident, Teresa realizes that in fact Sergio proposed to her only to have sex with "a liberated gringa" (100). As a result, Teresa's disorienting experiences in Mexico bring to mind Malinche's plight and, in particular, how alienated she must have felt after being betrayed and treated as a commodity by her own people, given that La Malinche was "victimized by patriarchy well before she was victimized by Eurocolonialism" (Pratt 867). Thus, by offering a more candid representation of heterosexual relationships, in which women are often betrayed by men of their own ethnic/racial kin, Castillo openly questions the idea of the "female traitor of 
the nation" that is attributed to La Malinche and by extension to those Chicanas who do not comply with established gender expectations.

The ever-present threat of rape and sexual violence in the novel further alludes to La Malinche. At the same time, Castillo subverts sexist assumptions that tend to blame the female victim for being raped, and instead presents sexual violence as an aggressive form of male betrayal equally perpetrated by Mexican men, as it was perpetrated by European men during the Conquest. In fact, many of the Mexican men Teresa and Alicia meet strive to gain their trust only to betray that trust afterward, when the opportunity arises. One prime example of this is Alvaro Pérez Pérez, Teresa's colleague, who, in Letter Sixteen, after inviting Teresa to spend a few days on his father's ranch outside a quaint Mexican town, he begins to argue with her, when he realizes that Teresa is not going to spend the night with him. Later on, to make things worse, Alvaro barges in Teresa and Alicia's bedroom, but the two young women are prepared and have barricaded their door to avoid being ambushed (Letters 58). Moreover, Teresa decries the fact that both she and Alicia are perceived by men in Mexico as "revolting," just because they are women traveling without a male companion, something which is seen as the "greatest transgression" (65-66). Thus, even though they both "hoped for respect as human beings," they are instead "susceptible to ridicule, abuse, disrespect" (65) and have to be "on guard" all the time, a maneuver which "was draining" (77). Norma Alarcón insightfully asserts that "[b]ecause Malintzin aided Cortes in the Conquest of the New World, she is seen as concretizing woman's sexual weakness and interchangeability, always open to sexual exploitation," whether it be seduction or rape (184). Thus, Teresa as a twentieth-century Chicana, who aspires to equality, is still struggling to be respected in Mexico, a patriarchal society that refuses to see women as equals worthy of respect and in which men still use tactics of domination to deceive or abuse women.

Another example of the misogynistic attitude that perpetuates sexual violence occurs when Teresa and Alicia are in Veracruz, which Teresa calls "the City of Babylonia" (Letters 85). First, Alicia escapes "gang rape at [a] university auditorium" (92), thanks to Teresa's fierce and instant response as she yells at the men who advance to "devour" Alicia to "LEAVE HER ALONE," while trembling with rage (84). A final example of the ubiquitous threat of sexual violence occurs right after this incident, when Señor Montes, the head of the engineering department of the state of Veracruz, and Señor Salazar offer to give Teresa and Alicia a ride to Mexico City (94). Before departing, Teresa realizes that their two male engineer friends, Ponce and Luis, who work for Señor Salazar and have offered their hospitality to Teresa and Alicia, "just turned [them] over to the Romans for a few measly gold coins" (94-95), as if they were "object[s] of exchange" (Cypess 153). Teresa also realizes how these two conservative middle-aged Mexican men perceive them, and then her mind immediately starts racing to find a way out of a violent situation that "might likely ensue" (Letters 95), during the approximately three-hundred kilometer journey. As a survival tactic, Teresa pretends that she is both a Professor of Anthropology traveling with a respectable research objective, and that she has a father expecting her to return home (96). In addition, Alicia lies about her and Teresa, stating that they come from "respected families" (97). To top it off, the next day they both take 
their "masquerade" one step further by pretending to be "the picture of the collegiate daughters whose loving parents would be waiting anxiously for their return" (98). Alarcón points out that one of the central, sexual political themes that Chicana literature explores, as inspired by Malintzin, is precisely how "women are seen not just by one patriarchy but by all as rapeable and sexually exploitable" (187). As a result, Teresa and Alicia go to great lengths to avoid being sexually assaulted and trick the time-honored and pervasive androcentric narrative of machismo, according to which women, who travel alone and are not members of a prominent family, are fair game for rape. Moreover, Teresa, as an educated feminist and a subversive, contemporary "Malinche," fully apprehends the deep-rooted misogyny and, therefore, she becomes an efficient interpreter and reader of men's intentions, while also undermining the belief that women are easy prey. Thus, Teresa is resourceful and knowledgeable enough to circumvent these aggressions and to counteract patriarchy's hypocrisies in order to ward off sexual violence.

Another point that connects Teresa to La Malinche is her problematic relationship with her mother, which exposes the pattern of older women's complicity in patriarchy, due to the overpowering influence of a male-dominated society. More specifically, Teresa's mother initially disapproves of her daughter's separation from her husband, so both mother and daughter "tried to keep out of each other's way" (Letters 35). Then, when the wealthy Sergio Samora proposes to Teresa, her mother is so "ecstatic" about the prospect of her daughter marrying off to a Mexican millionaire that she is even willing to "take precautions" to make Teresa's other marriage seem as if it never happened, and Teresa can then be "redeemed" (67). However, when Sergio abandons Teresa and she goes back to Chicago, her mother tells her unsympathetically: "You were married, divorced, been around, a veteran of various wars ... How could you have expected him to take you seriously? Men like that, with status, money, use women like you for playthings!" (100). Teresa is devastated by her mother's insensitive response and she leaves her mother's home for good "without saying good-bye" (100), because after this her family rejects her and "want[s] no part of [her]" (109). Alarcón incisively explains how misogyny is internalized even by mothers, who pass it down to their daughters, "[b]ecause the myth of Malintzin pervades not only male thought but ours too ... as well as our mothers,' who are entrusted with the transmission of culture" (183). Therefore, it could be argued that Teresa's mother's behavior evokes to some extent how Malinche's mother betrayed her own daughter and sold her out to benefit her son. This maternal betrayal renders both La Malinche and Teresa as outcasts in their own communities and both stories serve as a reminder of how insignificant daughters can end up in the patriarchal family structure that prioritizes sons or sons-in-law to the detriment of a more gratifying mother-daughter bond.

The way in which Teresa experiences the ambivalence of motherhood indirectly evokes once again the archetype of La Malinche. Castillo, however, enriches it by coalescing some elements from the other two Mexican archetypal mother figures: La Llorona, and La Virgen de Guadalupe. In Letter Thirty-One, Teresa describes the heartbreaking experience of an abortion after having conceived a baby by Alexis Valladolid, Alicia's distant cousin from Spain (Letters 105). Teresa 
makes the excruciating decision to have an abortion, a traumatic experience during which she pleads the doctor to stop, and which she describes afterward to Alexis as "having life sucked out" of her before throwing him out (114-16). All this demonstrates that Teresa is filled with crippling guilt and suffers enormously during and after the abortion as she repeats: "i killed my baby" (116). However, even though it is a very painful decision, Teresa makes it consciously, probably because of the fact that Alexis is a racist, a man who believes that being an Indian is even worse than being a Nazi (107). Hence, Teresa does not want be linked with him for the rest of her life and decides "to be rid of him" (116). Jungian psychoanalyst Clarissa Pinkola Estés claims that "[s]ometimes the La Llorona tale is told as a story about Ce. Malinalli or Malinche" (qtd. in Gonzalez 160). Nevertheless, Maria Gonzalez argues that La Malinche is "the mother/whore of the Mexican mythos," hated for her apparent selling-out to the European conquerors (159), she is a woman who just has to be controlled, whereas La Llorona is feared, uncontrollable and "capable of enormous destruction" (161). Therefore, it could be argued that in Letter ThirtyOne, Teresa symbolically transforms into a contemporary Llorona, by having an abortion and then grieving for it, probably because she wants to avoid at all costs repeating Malinche's tale of having the child of a Spanish, racist man, something that will determine the rest of her life.

As a single mother of the child she has later and after the abortion, Teresa reverses La Malinche's loss of her son, Martín, whom Cortés sent to Spain to be educated over her objections (Bernal Díaz, qtd. in Pratt 866). Teresa only implies that her son's father is her ex-husband Libra, as if the child's father is irrelevant, because Teresa is already determined to raise her only son alone as a single mother, one who wants to instill into him the values of gender equality (Letters 136), and avoid the predicament of androcentric indoctrination. Furthermore, Castillo introduces some elements of the archetype of La Virgen de Guadalupe, given that Teresa is a devoted nurturing mother, and considers her son "a miracle" (134). In addition, Teresa wants to have her son baptized as a Catholic, so that he can have a "spiritual insurance of another's protection," and asks Alicia to be his godmother because their "views on parenting are similar" (134), even though Alicia is not religious. According to Gloria E. Anzaldúa, Chicana/o culture has "tres madres" or three mothers: "Guadalupe, the virgin mother who has not abandoned us, $L a$ Chingada (Malinche), the raped mother whom we have abandoned, and La Llorona, the mother who seeks her lost children and is a combination of the other two" (30). Ambiguity surrounds these three "Mothers," whose true identity has been obscured to encourage "the virgen/puta (whore) dichotomy" (31). Interestingly enough, in The Mixquiahuala Letters the three archetypal mothers of the Mexican culture converge. Indeed, Teresa's narrative arch suggests an alternative Xicanista vision that perceives women as culturally polysemous individuals. By doing so, Castillo rejects dehumanizing patriarchal dichotomies that superficially pigeonhole women and mothers into good and bad.

To conclude, this article illustrated that Ana Castillo has created a compelling late-twentieth-century Chicana character like Teresa, a woman that personifies a contemporary Malinche, and a quintessential female outcast, in order 
to expose the sexist double standards Chicana women are subjected to. Castillo brings to the surface the contradictions of patriarchal victim blaming by highlighting how Teresa is betrayed by her relatives, men of her own ethnic background, and even by her own mother. Thus, Teresa evokes the way in which La Malinche was unjustly scapegoated and blamed as a traitor, when in reality both La Malinche and Teresa have been betrayed by their own people. The superficial interpretation of Malinche's story based on an androcentric reading of complex historical events has been perpetuated for centuries, and has influenced the way in which Chicanas are perceived within their communities, because blaming women without examining the wider sociopolitical context that shapes their decisions is customary under patriarchy. Finally, by centering on the friendship between Teresa and Alicia, which is often dialectic in nature as regards gender issues, Castillo undertakes the difficult task of delving into the female experience, and proposes a Chicana feminist vision, or a Xicanista consciousness, that emphasizes the understanding of the past in order to be able to envision a better future. 


\section{WORKS CITED}

Alarcón, Norma. "Chicana’s Feminist Literature: A Re-Vision Through Malintzin/or Malintzin: Putting Flesh Back on the Object." This Bridge Called My Back: Writings by Radical Women of Color. Ed. Cherríe Moraga \& Gloria E. Anzaldúa. Kitchen Table: Women of Color Press, 1983. 182-190.

AnZaldúa, Gloria. Borderlands/La Frontera: The New Mestiza. Aunt Lute Books, 1987.

Candelaria, Cordelia. "La Malinche, Feminist Prototype." Frontiers 5/2 (1980): 1-6. Semantics Scholars, http://pdfs.semanticscholar.org/7cd1/628b13b127bdc7d1e9668021437f7e131fcb. pdf. Accessed 18 Mar. 2020.

Carson, Benjamin D. “The Chicana Subject in Ana Castillo's Fiction and the Discursive Zone of Chicana/o Theory.” Bilingual Review / La Revista Bilingüe 28/2 (May-Aug 2004-2007): 109126. JSTOR, https://www.jstor.org/stable/25745853?seq=1\#metadata_info_tab_contents. Accessed 4 June 2020.

Castillo, Ana. Massacre of the Dreamers: Essays on Xicanisma. 1994. Plume, 1995.

Castillo, Ana. The Mixquiahuala Letters. 1986. Anchor Books, 1992.

Cypess, Sandra Messinger. La Malinche in Mexican Literature: From History to Myth. U of Texas P, 1991.

Gonzalez, Maria. "Love and Conflict: Mexican American Women Writers as Daughters." Women of Color: Mother-Daughter Relationships in 20th-Century Literature. Ed. Elizabeth BrownGuillory. U of Texas P, 1996. 153-171.

Mullen, Harryette. “'A Silence between Us like a Language': The Untranslatability of Experience in Sandra Cisneros's Woman Hollering Creek.” MELUS 21/2 (Summer 1996): 3-20. JSTOR, https://www.jstor.org/stable/467946?seq=1\#metadata_info_tab_contents. Accessed 9 Oct. 2018.

Pratt, Mary Louise. "Yo Soy La Malinche': Chicana Writers and the Poetics of Ethnonationalism." Callaloo 16/4 (Autumn 1993): 859-873. JSTOR, https://www.jstor.org/stable/2932214? seq=1\#metadata_info_tab_contents. Accessed 13 Mar. 2020.

Weissberger, Barbara F. “Ana Castillo’s The Mixquiahuala Letters: A Queer Don Quijote." Letras Femeninas 33/2 (2007): 9-23. JSTOR, https://www.jstor.org/stable/23021992?seq=1\# metadata_info_tab_contents. Accessed 4 June 2020. 
